\title{
Postmortem radiographic, histological and bacteriological studies of terminal respiratory infections and other pulmonary lesions in hospital and non-hospital necropsies
}

\author{
PAAVO PÄÄKKÖ,* TERTTU SÄRKIOJA,† JORMA HIRVONEN,† TAPIO NURMI,‡ \\ REIJO LAHTI,§ SEPPO SUTINEN*
}

From the Departments of Pathology, ${ }^{*}$ Forensic Medicine, $\dagger$ Medical Microbiology, $\ddagger$ and Diagnostic Radiology, \& University of Oulu, Finland

SUMMARY One lung from 109 unselected hospital and 43 unselected non-hospital necropsies was studied using postmortem radiography with histological verification. Signs of acute bacterial infection, including bronchiolitis or bronchopneumonia, were present in $42.2 \%$ of the hospital necropsies and infection was the immediate cause of death in $8.3 \%$. There was only one case of incipient bronchopneumonia among the non-hospital necropsies. Emphysema was the most common other pulmonary lesion in both groups.

Gram negative bacteria were found significantly more often in the bronchial mucus of lungs with any pulmonary lesion, particularly those with signs of bacterial infection, than in the bronchial mucus of morphologically normal lungs in both groups of patients. In addition, the frequency of infections was associated with length of stay in hospital. This may reflect the prevalence of Gram negative infections in hospitals.

Bacterial pneumonia is common in postmortem material, ${ }^{1-4}$ and is found in about half of the cases seen at necropsy. There are no studies of the simultaneous prevalence of other lesions in the lungs at necropsy, which moreover, might predispose to infection. The pathological verification of pneumonia has largely been based on macroscopic observations. In our experience, however, even considerable pneumonic foci may go undetected macroscopically, whereas radiography of excised and air inflated lungs ${ }^{5}$ has proved reliable in detecting even minute pneumonic changes. ${ }^{\circ}$

Colonisation of the respiratory tract by Gram negative bacilli has been shown in patients in hospital. $^{7-9}$ We have also found a significant association between length of stay in hospital and the occurrence of Gram negative bacteria both in the bronchial mucus and heart blood at necropsy (Pääkkö et al, unpublished observations) but correlations between postmortem bacteriology and morphological pulmonary lesions studied systematically have not yet been presented.

Accepted for publication 13 June 1984
In this study we have used postmortem radiography of excised lungs with histological verification to determine how often pulmonary lesions, especially terminal bacterial infections, occur in hospital and non-hospital necropsies and how often infection is the immediate cause of death.

\section{Material and methods}

The material consisted of 152 unselected adult necropsies: 109 represented deaths in hospital and 43 deaths outside hospital. The hospital series comprised 67 men and 42 women (aged 22 to 89 years; mean 66 years); the non-hospital series consisted of 36 men and 7 women (aged 15 to 80 years; mean 53 years). Necropsies of the former series were performed one to eight days after death (average 3.9) and those of the latter one to 11 days after death (average 4.4). Almost all bodies were placed in a refrigerator within $4 \mathrm{~h}$ of death and preserved at $4^{\circ} \mathrm{C}$ until necropsy. In 12 forensic cases the bodies had been left at room temperature for from $5 \mathrm{~h}$ to 7 days (mean 41 hours) before being placed in a refrigerator. Of the hospital necropsies, 69 right and 
Table 1 Causes of death in hospital and non-hospital patients

\begin{tabular}{lll}
\hline Cause of death & \multicolumn{2}{c}{ Type of patient } \\
\cline { 2 - 3 } & Hospital & Non-hospital \\
\hline Cardiovascular diseases & 68 & 18 \\
Ischaemic heart diseases & 38 & 16 \\
Cerebrovascular disease & 19 & \\
Others & 11 & \\
Malignant neoplasms & 22 & \\
Respiratory organs & 4 & \\
Others & 18 & \\
Respiratory diseases & 9 & \\
Emphysema & 4 & \\
Asthma & 2 & 2 \\
Others & 3 & \\
Other natural deaths & 10 & \\
Violent deaths & & \\
(suicides, accidents, etc) & 109 & 43 \\
Total & & \\
\hline
\end{tabular}

40 left lungs were studied; of the non-hospital necropsies 37 right and 6 left lungs were studied. Table 1 gives the main causes of death in hospital and non-hospital patients.

An aspirate of bronchial mucus for culture was obtained with a sterile disposable syringe from the lower lobe bronchus as deep as possible immediately after the severance of the main bronchus. After aspiration, a sterile needle with a rubber stopper was attached to the syringe. A heart blood sample was aspirated from the left ventricle before dissecting the lungs and heart and immediately injected into blood culture bottles at room temperature (Hemobact A and B, Orion Diagnostica, Finland). All microbiological specimens were taken to the bacteriology laboratory as soon as possible, where Gram staining, cultures of aerobic and anaerobic bacteria and fungi, and isolation of chlamydia were performed within about $1 \mathrm{~h}$ of the collection of the specimens. The mucus and blood specimens were cultured on blood, chocolate, and lactose agar and incubated for $96 \mathrm{~h}$ under both aerobic and anaerobic conditions before being discarded as negative. Positive cultures were immediately subcultured on appropriate solid agar media for isolation of colonies. Final species identification was made using differential media and tests. ${ }^{10}$ Sabour and media for the recovery of fungi were used. The isolation of chlamydia was performed using cultured McCoy cells. ${ }^{1}$

For the recognition of pulmonary lesions one lung of each patient was excised and radiographed after tying the blood vessels during continuous air inflation, fixed intrabronchially with a formalin, polyethylene glycol, and alcohol solution, dried by air insufflation, and sliced sagittally. ${ }^{5}$ For histological examination, five $5 \times 5 \mathrm{~cm}$ tissue blocks were collected systematically. In addition, a large number of tissue blocks were taken from interesting areas seen in the radiographs. Sections $(15 \mu \mathrm{m})$ mounted on photographic glass slides were first examined by projecting them on to a screen, and the lesions thus seen were further studied microscopically at higher power on corresponding $6 \mu \mathrm{m}$ sections.

In this study the following lesions were recorded separately: inflammatory changes, emphysema, chronic congestion, alveolar haemorrhage, infarction, scars, non-specific interstitial fibrosis, bronchiectasis, bronchogenic cysts, and neoplasms. Alveolar and interstitial (lobular) oedema were not included here but were regarded as a sign of the mechanism of death.

\section{INFLAMMATORY CHANGES}

No case of acute lobar pneumonia was found in either series. Acute bronchiolitis and lobular pneumonia were regarded as signs of acute bacterial infection in the lung tissue. Acute bronchiolitis manifested itself as an inflammatory exudate in the lumen and mucosa of the bronchioli. ${ }^{2}$ Intra-alveolar polymorphonuclear leucocytic exudate without concomitant interstitial inflammatory infiltration was diagnosed as lobular or bronchopneumonia. If the inflammatory focus was not visible in the radiograph or was otherwise small, solitary, and limited, we classified the lesion as incipient. Other types of inflammation of the lung tissue such as usual interstitial pneumonia, ${ }^{12}$ tuberculous pneumonia, chronic lobar pneumonia with granulomatous necrotic inflammation, carnification pneumonia, ${ }^{2}$ and granulomatous inflammation were also recorded separately.

\section{OTHER PULMONARY LESIONS}

The severity of emphysema was evaluated on the basis of the radiographs of excised lungs ${ }^{13}$ and gross specimens using a set of photographs of standard grades. ${ }^{14}$ Grades $10-20$ represented mild, grades 30-50 moderate, and grade 60 or more severe emphysema. ${ }^{15}$ Emphysema was classified as centrilobular, panlobular, or paracicatricial. ${ }^{15}$

Abundant alveolar macrophage collections ("heart failure cells") were regarded as a sign of chronic congestion. Necrosis of tissue with haemorrhage was required for the diagnosis of fresh infarction. ${ }^{16}$ Scars included parenchymal and pleural scars, as well as foci of tuberculosis. Non-specific interstitial fibrosis included local alveolar wall fibrosis, fibrosis of the lobular septa, and honeycombing of the lung. ${ }^{12}$ Neoplastic lesions included primary neoplasms and pulmonary metastases.

Information about length of stay in hospital was obtained from the hospital records. The significance of associations was determined using the $\chi^{2}$ test or 
Table 2 Macroscopic, radiographic and/or histological findings in lungs from hospital and non-hospital necropsies*

\begin{tabular}{|c|c|c|c|c|}
\hline \multirow[t]{2}{*}{$\begin{array}{l}\text { Macroscopic, radiographic } \\
\text { and/or histological funding }\end{array}$} & \multicolumn{2}{|c|}{$\begin{array}{l}\text { Hospital } \\
\text { necropsies }\end{array}$} & \multicolumn{2}{|c|}{$\begin{array}{l}\text { Non-hospital } \\
\text { necropsies }\end{array}$} \\
\hline & No & $(\%)$ & No & $(\%)$ \\
\hline $\begin{array}{l}\text { Normal lung } \\
\text { Inflammatory changes } \dagger \\
\text { Emphysema (all grades) } \\
\text { Chronic congestion } \\
\text { Alveolar haemorrhage } \\
\text { Infarction } \\
\text { Scars } \\
\text { Non-specific interstitial fibrosis } \\
\text { Bronchiectasis } \\
\text { Bronchogenic cyst } \\
\text { Neoplasm } \\
\text { Total }\end{array}$ & $\begin{array}{r}10 \\
53 \\
54 \\
37 \\
18 \\
8 \\
40 \\
9 \\
1 \\
1 \\
4 \\
109\end{array}$ & $\begin{array}{r}(9.2) \\
(48.6) \\
(49.5) \\
(33 \cdot 9) \\
(16.5) \\
(7.3) \\
(36.7) \\
(8.3) \\
(0.9) \\
(0.9) \\
(3.7)\end{array}$ & $\begin{array}{r}10 \\
3 \\
19 \\
10 \\
5 \\
4 \\
13 \\
- \\
-\end{array}$ & $\begin{array}{r}(23.3) \\
(7 \cdot 0) \\
(44 \cdot 2) \\
(23 \cdot 3) \\
(11 \cdot 6) \\
(9.3) \\
(30.2)\end{array}$ \\
\hline
\end{tabular}

*Some lungs showed more than one lesion.

tSignificant difference between the two groups $(p<0.003)$.

Student's $t$ test or by calculating the standard error of the difference between two proportions. ${ }^{17}$

\section{Results}

\section{PULMONARY LESIONS}

Macroscopic and radiographic and/or histological findings in the lungs from the hospital and nonhospital necropsies are shown in Table 2. Most of the lungs showed more than one lesion, and the proportion of completely normal lungs was low in both groups ( $9.2 \%$ and $23.3 \%$, respectively).
Table 3 Morphological signs of inflammation in lungs from hospital and non-hospital necropsies

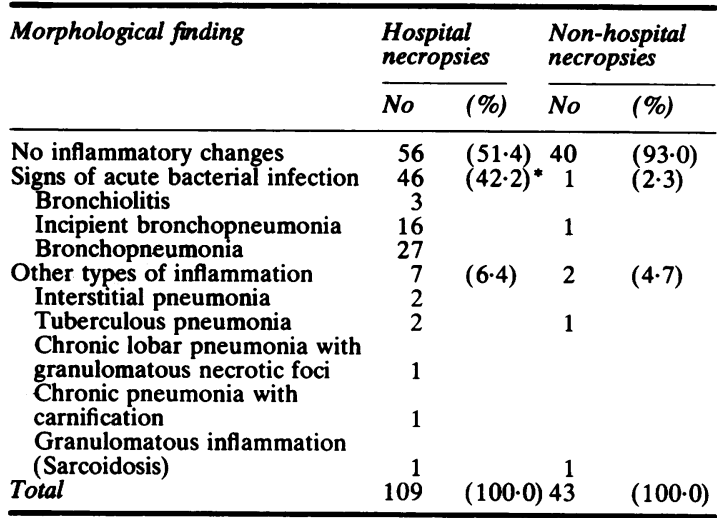

*Significant difference between two groups $(p<0.003)$.

\section{INFLAMMATORY LESIONS}

Morphological signs of inflammation found in the lungs from the hospital and non-hospital necropsies are shown in Table 3. The hospital series contained significantly more cases with acute inflammation than the non-hospital series. In nine of the hospital series $(8.3 \%)$ bronchopneumonia was considered to be the immediate cause of death. In addition, some other type of inflammation was seen in seven lungs $(6.4 \%)$. Two of these represented interstitial pneumonia, and five chronic or granulomatous inflammation. Two of the latter were confirmed as

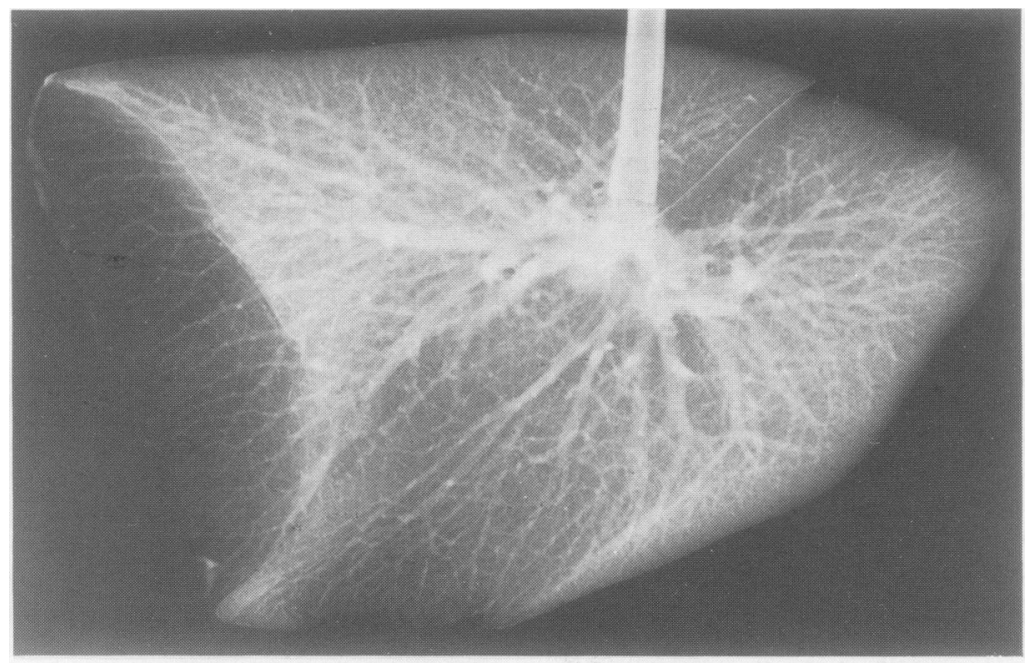

Fig. 1 Postmortem radiograph of a normal air inflated, excised right lung showing regular branching blood vessels and a fine capillary background. Bronchial mucus culture showed Str viridans and clostridium. $\times 0.50$. 
Table 4 Hospital necropsies: number of occasions different species were isolated from bronchial mucus specimens correlated with macroscopic radiographic and/or histological findings of any pulmonary lesion

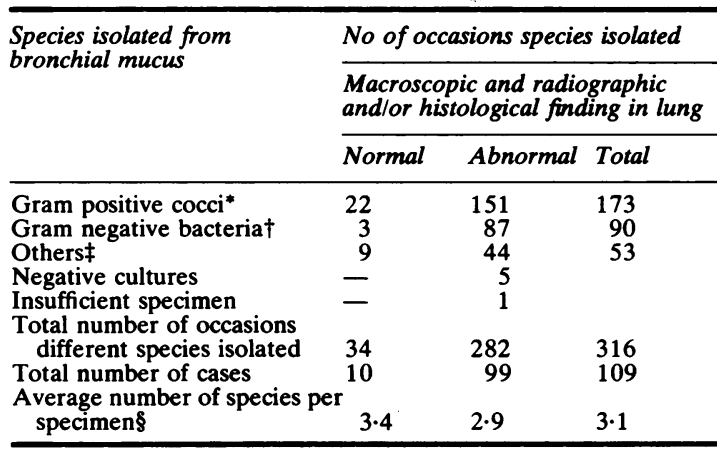

$\chi^{2}=8.00, \mathrm{p}<0.025$ (negative cultures and insufficient specimen excluded).

*Str viridans, Str non-haemolyticus, Str faecalis, Staph aureus, Str $\beta$-haemolyticus, Staph epidermidis, Diplococcus pneumoniae, sarcina, unspecified.

$\dagger E$ coli, klebsiella, proteus, enterobacter, pseudomonas, bacteroides, serratia, citrobacter, haemophilus, acinetobacter, unspecified.

¥Gram negative cocci: neisseria, veillonella, unspecified.

Gram positive rods: difteroid, bacillus, clostridium, corynebacterium

Fungi: candida, Torulopsis glabrata, Geotrichum candidum, aspergillus.

Minibacterium: chlamydia.

8Difference between groups not significant.
Table 5 Non-hospital necropsies: number of occasions different species were isolated from bronchial mucus specimens correlated with macroscopic, radiographic and/ or histological findings of any pulmonary lesion

\begin{tabular}{|c|c|c|c|}
\hline \multirow{3}{*}{$\begin{array}{l}\text { Species isolated from } \\
\text { bronchial mucus }\end{array}$} & \multicolumn{3}{|c|}{ No of occasions species isolated } \\
\hline & \multicolumn{3}{|c|}{$\begin{array}{l}\text { Macroscopic and radiographic } \\
\text { and/or histological finding }\end{array}$} \\
\hline & Normal & Abnormal & Total \\
\hline $\begin{array}{l}\text { Gram positive cocci* } \\
\text { Gram negative bacteria } \dagger \\
\text { Others } \ddagger \\
\text { Negative culture } \\
\text { Total number of occasions }\end{array}$ & $\begin{array}{r}18 \\
1 \\
5 \\
1\end{array}$ & $\begin{array}{l}56 \\
23 \\
14\end{array}$ & $\begin{array}{l}74 \\
24 \\
19\end{array}$ \\
\hline $\begin{array}{l}\text { different species isolated } \\
\text { Total number of cases }\end{array}$ & $\begin{array}{l}24 \\
10\end{array}$ & $\begin{array}{l}93 \\
33\end{array}$ & $\begin{array}{r}117 \\
43\end{array}$ \\
\hline $\begin{array}{l}\text { Average number of species pe } \\
\text { specimen } \S\end{array}$ & $2 \cdot 4$ & $2 \cdot 8$ & $2 \cdot 8$ \\
\hline
\end{tabular}

$\chi^{2}=4.95, p<0.05$ (negative culture excluded, gram positive cocci and others combined).

${ }^{*}$ Str viridans, Str non-haemolyticus, Staph aureus, Diplococcus pneumoniae, Str $\beta$-haemolyticus, Staph epidermidis.

$t E$ coli, Haemophilus infuenzae, Klebsiella, bacteroides, enterobacter, proteus, pseudomonas.

$¥$ Gram negative cocci: neisseria.

Gram positive rods: difteroid, clostridium, corynebacterium, unspecified.

Fungi: candida.

§Difference between groups not significant.

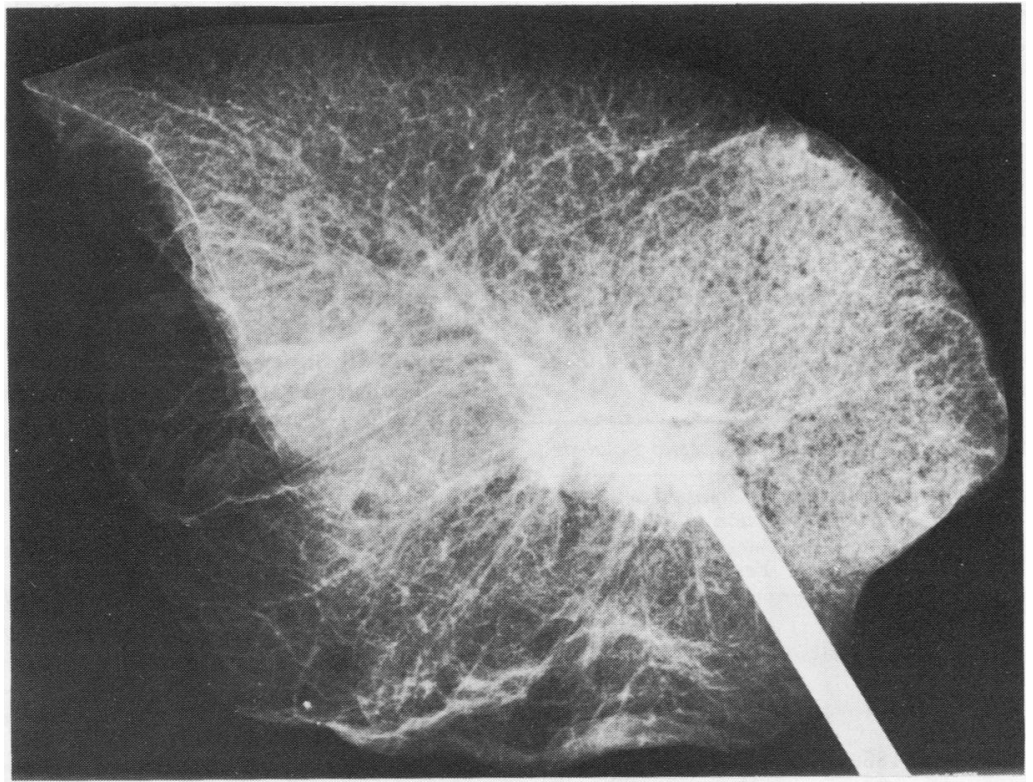

Fig. 2 Postmortem radiograph of an air inflated, excised right lung exhibiting moderate centrilobular emphysema (grade 40). There is rounding of the anterior margin; small blood vessel densities irregularly branched, narrowed, and reduced; small tissue defect translucencies associated with alveolar oedema are evident in the apex and in the posterior parts of the upper lobe as well as some larger ones anteriorly. Bronchial mucus culture showed Staph aureus, klebsiella, Str viridans and streptococcus non-haemolyticus. $\times 0.68$. 


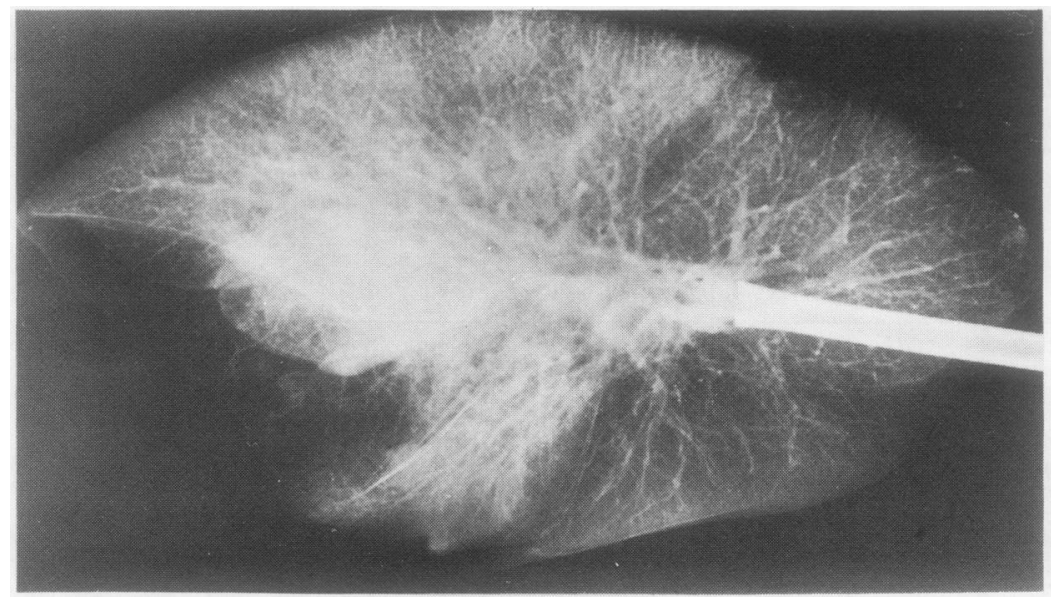

Fig. 3 Postmortem radiograph of an air inflated, excised right lung exhibiting confuent alveolar consolidation in the anterobasal segment of the lower lobe and coarse macular opacities with indistinct borders in the medial lobe; both changes are typical of lobular or bronchoneumonia. Bronchial mucus culture showed Escherichia coli, Str viridans, and streptococcus non-haemolyticus. $\times 0.54$.

tuberculosis, and one was interpreted as sarcoidosis.

In the 43 non-hospital necropsies one lung showed incipient bronchopneumonia $(2 \cdot 3 \%)$, one tuberculosis, and one sarcoidosis.

\section{CORRELATIONS WITH POSTMORTEM \\ BACTERIOLOGY}

Gram negative organisms were seldom isolated from the bronchial mucus of morphologically normal lungs (Fig. 1) in either hospital (Table 4) or nonhospital necropsies (Table 5). In the non-hospital group the bronchial mucus from the lungs showing emphysema (Fig. 2) of any degree contained Gram

Table 6 Hospital necropsies: number of occasions different species were isolated from bronchial mucus specimens correlated with morphological signs of acute bacterial respiratory infection

\begin{tabular}{|c|c|c|c|}
\hline \multirow{3}{*}{$\begin{array}{l}\text { Species isolated from } \\
\text { bronchial mucus }\end{array}$} & \multicolumn{3}{|c|}{ No of occasions species isolated } \\
\hline & \multicolumn{3}{|c|}{$\begin{array}{l}\text { Morphological signs of acute } \\
\text { bacterial infection in lung }\end{array}$} \\
\hline & None & Yes & Total \\
\hline $\begin{array}{l}\text { Gram positive cocci } \\
\text { Gram negative bacteria } \\
\text { Othersł } \\
\text { Negative cultures } \\
\text { Insufficient specimen } \\
\text { Total number of occasions }\end{array}$ & $\begin{array}{r}105 \\
41 \\
39 \\
4 \\
1\end{array}$ & $\begin{array}{r}68 \\
49 \\
14 \\
1 \\
0\end{array}$ & $\begin{array}{r}173 \\
90 \\
53\end{array}$ \\
\hline $\begin{array}{l}\text { different species isolated } \\
\text { Total number of cases } \\
\text { Average number of species per } \\
\text { specimen* }\end{array}$ & $\begin{array}{r}185 \\
63 \\
\mathbf{r} \\
3.0\end{array}$ & $\begin{array}{r}131 \\
46 \\
2 \cdot 8\end{array}$ & $\begin{array}{l}316 \\
109\end{array}$ \\
\hline
\end{tabular}

negative rods more often and Gram positive cocci and other microbes less often than bronchial mucus from non-emphysema lungs, though the difference was not significant. In the hospital series, however, no such trend was found. In neither series were there any differences in the cultures of heart blood between those cases with normal morphology and those with pulmonary lesions.

In hospital necropsies Gram negative bacteria were cultured significantly more often from the bronchial mucus of lungs showing morphological signs of pneumonia or bronchiolitis (Fig. 3) than from those without such signs $(p<0.005)$ (Table 6$)$. The average number of occasions on which different species were isolated from each bronchial mucus specimen did not differ, however, between cases with morphological signs of pneumonia or bronchiolitis and those without. In six hospital necropsies with morphological signs of pneumonia or bronchiolitis only one type of bacterium grew from the bronchial

Table 7 Hospital necropsies: length of stay in hospital correlated with signs of acute bacterial pneumonias in 109 lungs

\begin{tabular}{lllc}
\hline $\begin{array}{l}\text { Length of stay in hospital } \\
\text { (days) }\end{array}$ & \multicolumn{4}{l}{$\begin{array}{l}\text { Morphological signs of acute } \\
\text { pneumonia }\end{array}$} \\
\cline { 2 - 4 } & None & Yes & Total \\
\hline $1-3$ & 33 & 15 & 48 \\
4 or more & 30 & 31 & 61 \\
Total & 63 & 46 & 109 \\
\hline
\end{tabular}

$x^{2}=4.22, p<0.05$. 
mucus. In these, the bacteria probably representing the cause of infection were as follows: Proteus mirabilis twice, and Escherichia coli, Klebsiella aerogenes, Enterobacter cloacae, and Streptococcus viridans once each. Only one non-hospital necropsy showed morphological signs of pneumonia or bronchiolitis; the bronchial mucus culture yielded $\mathrm{Pr}$ mirabilis and Corynebacterium freundi. In the hospital series the cultures of heart blood did not differ between cases with morphological signs of acute bacterial infection and those without.

\section{LENGTH OF STAY IN HOSPITAL}

In hospital necropsies morphological signs of pneumonia and bronchiolitis were found more often in the lungs of patients who had been treated in hospital for four days or more than in those whose hospital stay had lasted a shorter time $(p<0.05)$ (Table 7).

\section{Discussion}

Postmortem radiography of air inflated lung is a sensitive and accurate method and is suitable for studying the prevalence of any pulmonary lesions, especially the simultaneous occurrence of different pathologies throughout the lung. Acute bacterial respiratory infections are responsible for a high proportion of terminal illnesses; they occur in more than half of the cases seen at necropsy. ${ }^{13418} \mathrm{We}$ found postmortem morphological signs of acute bacterial infection, including bronchiolitis and bronchopneumonia, in $42.2 \%$ of the lungs from hospital necropsies; bronchopneumonia was the immediate cause of death in $8.3 \%$. This figure is similar to the findings of Kneeland and Price ${ }^{3}$ and Fedson and Baldwin, ${ }^{19}$ but in elderly patients bronchopneumonia may account for $14 \%$ of all deaths. ${ }^{20}$ Unlike the hospital series, only one non-hospital necropsy showed morphologically incipient bronchopneumonia. This is similar to the findings of Mays et al, ${ }^{21}$ who reported no evidence of acute pneumonia in 54 medicolegal necropsies while $32 \%$ of the specimens from 336 hospital necropsies showed signs of acute inflammation.

In previous studies, however, the pathological verification of pneumonia was based on macroscopic and histological observations. In our experience macroscopic examination is often misleading and the small tissue blocks collected for histology may not be representative. By using postmortem radiography of air inflated lung ${ }^{5}$ it is possible to distinguish a pneumonic focus up to $2 \mathrm{~mm}$ in diameter. ${ }^{6} \mathrm{In}$ addition, the tissue blocks for histology in the present study were collected systematically and a large number of additional ones were taken from interest- ing areas seen in the radiographs.

In this study we found an association between the occurrence of Gram negative bacteria in the bronchial mucus at necropsy and the presence of pulmonary lesions of any kind in hospital and non-hospital necropsies. Valenti $e t a^{9}$ found that being bedridden with respiratory disease contributed most to oropharyngeal colonisation with Gram negative bacilli in elderly patients. In our material, however, the pulmonary lesions did not always produce an apparent clinical respiratory disease. Thus even slight damage to the lung parenchyma may predispose to the colonisation of Gram negative bacteria in the bronchial tree.

In our non-hospital series, in lungs showing emphysema, although often mild, the bronchial mucus yielded more Gram negative bacteria than mucus from the unaffected lungs, although the difference was not significant. It may be that mild emphysema, by affecting the clearance system and predisposing to the colonisation of Gram negative bacteria, is clinically important. There is clinical evidence that the lower respiratory tracts of patients with chronic bronchitis are often colonised by bacteria, especially Haemophilus infuenzae. ${ }^{22-24}$ In the present study, however, haemophilus was found only rarely.

According to Kneeland and Price ${ }^{3}$ most lungs with pneumonia yield abundant growth of bacteria, whereas normal lungs are mainly free of bacteria. This is in accordance with the study of Koneman et al. ${ }^{2526}$ In our hospital necropsies bronchial mucus cultures almost always yielded growth of some bacteria both from lungs showing signs of acute bacterial infection and from those showing none, and there was no significant difference in the average number of occasions on which different species were isolated. There was, however, a highly significant association between the occurrence of Gram negative rods in the bronchial mucus and signs of acute bacterial infection in the lung tissue. The latter finding agrees with that of Mays et $\mathrm{al}^{21}$ and probably reflects oropharyngeal colonisation before death by Gram negative bacilli among the patients in hospital, ${ }^{79}$ predisposing them to nosocomial respiratory infections. ${ }^{8}$ This may have connections with the study of Fedson and Baldwin, ${ }^{19}$ who found that previous hospital care increased the risk of developing pneumonia. In the hospital necropsies we found signs of acute bacterial infection more often in the lungs of patients whose hospital stay had been four days or longer than in the lungs of patients whose hospital stay had been shorter.

We thank Mrs Eeva-Liisa Heikkinen, Mrs MarjaLeena Vahera, Mr Tapio Leinonen, and Mr Markku 
Koskela for technical assistance. This study was supported by grants for the Sigrid Juselius Foundation and the Finnish Anti-Tuberculosis Association, Helsinki, Finland.

\section{References}

'Smillie WG, Duerschner DR. The epidemiology of terminal bronchopneumonia. II The selectivity of nasopharyngeal bacteria in invasion of the lungs. Am J Hyg 1947;45:13-8.

${ }^{2}$ Spencer H. Pathology of the lung. 3rd ed. Vol 1. Oxford: Pergamon Press, 1977.

${ }^{3}$ Kneeland Y, Price KM. Antibiotics and terminal pneumonia. Am J Med 1960;29:967-79.

${ }^{4}$ Polednak AP. Postmortem bacteriology and pneumonia in a mentally retarded population. Am J Clin Pathol 1977; 67:190-5.

${ }^{s}$ Sutinen S, Pääkkö P, Lahti R. Post-mortem inflation, radiography, and fixation of human lungs: A method for radiological and pathological correlations and morphometric studies. Scand J Respir Dis 1979;60:29-35.

- Pääkkö P, Sutinen S, Lahti R. Pattern recognition in radiographs of excised air-inflated human lungs: II Acute inflammation in non-emphysematous lungs. Eur J Respir Dis 1981;62:33-45.

' Johanson WG, Pierce AK, Sanford JP. Changing pharyngeal bacterial flora of hospitalized patients. Emergence of Gramnegative bacilli. $N$ Engl J Med 1969;281:1137-40.

${ }^{8}$ Johanson WG, Pierce AK, Sanford JP, Thomas GD. Nosocomial respiratory infections with gram-negative bacilli. Ann Intern Med 1972;77:200-3.

${ }^{9}$ Valenti WM, Trudell RG, Bentley DW. Factors predisposing to oropharyngeal colonization with gram-negative bacilli in the aged. $N$ Engl J Med 1978;298:1108-11.

${ }^{10}$ Buchanan RE, Gibbons NE. Bergey's manual of determinative bacteriology. 8th ed. Baltimore: Williams and Wilkins Company, 1974.

"Gordon FB, Quan AI. Isolation of the trachoma agent in cell culture. Proc Soc Exp Biol Med 1965;118:354-9.

12 Liebow AA. Definition and classification of interstitial pneumonias in human pathology. Prog Resp Res 1975;8:1-33.

${ }^{13}$ Sutinen S, Pääkkö P, Lohela P, Lahti R. Pattern recognition in radiographs of excised air-inflated human lungs: IV
Emphysema alone and with other common lesions. Eur $J$ Respir Dis 1981;62:297-314.

${ }^{14}$ Thurlbeck WM, Dunnill MS, Hartung W, Heard BE, Heppleston AG, Ryder RC. A comparison of three methods of measuring emphysema. Hum Pathol 1970;1:215-26.

is Sutinen S, Vaajalahti P, Pääkkö P. Prevalence, severity, and types of pulmonary emphysema in a population of deaths in a Finnish city: Correlation with age, sex and smoking. Scand $J$ Respir Dis 1978;59:101-5.

${ }^{16}$ Spencer H. Pathology of the lung. 3rd ed. Vol 2. Oxford: Pergamon Press, 1977.

${ }^{17}$ Hill AB. Principles of medical statistics. 7th ed. Edinburgh: R and R Clark Ltd, 1961.

${ }^{18}$ Zanem-Lim OG, Zanen HC. Postmortem bacteriology of the lung by printculture of frozen tissue: A technique for in situ culture of microorganisms in whole frozen organs. J Clin Pathol 1980;33:474-80.

${ }^{19}$ Fedson DS, Baldwin JA. Previous hospital care as a risk factor for pneumonia. JAMA 1982;248:1989-95.

${ }^{20}$ Gerber IE. Terminal pneumonia in the aged. Mt Sinai $J$ Med 1980;47:166-7.

${ }^{21}$ Mays BB, Thomas GD, Leonard JS, Southern PM, Pierce AK, Sanford JP. Gram-negative bacillary necrotizing pneumonia: A bacteriologic and histopathologic correlation. J Infect Dis 1969; 120:687-97.

${ }^{22}$ Brumfitt W, Willoughby MLN, Bromley LL. An evaluation of sputum examination in chronic bronchitis. Lancet 1957; ii: $1306-9$.

${ }^{23}$ Lees AW, McNaught W. Bacteriology of lower-respiratory-tract secretions, sputum, and upper-respiratory-tract secretions in "normals" and chronic bronchitics. Lancet 1959;ii:1112-5.

${ }^{24}$ Laurenzi GA, Potter RT, Kass EH. Bacteriologic flora of the lower respiratory tract. $N$ Engl J Med 1961;265:1273-8.

${ }^{25}$ Koneman EW, Minckler TM, Shires DB, deJongh DS. Postmortem bacteriology: II Selection of cases for culture. Am J Clin Pathol 1971;55:17-23.

${ }^{26}$ Koneman EW, Davis MA. Postmortem bacteriology. III Clinical significance of microorganisms recovered at autopsy. Am J Clin Pathol 1974;61:28-40.

Requests for reprints to: Dr Paavo Pääkkö, Department of Pathology, University of Oulu, Kajaanintie 52 D, SF90220 Oulu 22, Finland. 